\title{
Viscoelastic Fluid in the Flow in Half-Spherical Gap
}

\author{
Hiroshi YAMAGUCHI and Masatoshi MORISHITA \\ Department of Mechanical Engineering, \\ Doshisha University, 1-3 Miyakotani, Kyo-tanabeshi \\ Kyoto 610-0321, Japan
}

\begin{abstract}
Flow of viscoelastic fluid contained between a stationary outer sphere and a rotating inner hemisphere is studied experimentally. In the present investigation, relatively low-concentration polyacrylamide-water solutions are used as viscoelastic fluid, and for the sake of comparison glycerin-water solutions are used as the Newtonian fluid.

In experiments, measurements of the rotational torque and thrust are carried out. Various transition phenomena of flow modes that are unique to viscoelastic fluids are investigated by flow visualization for a wide range of rotational Reynolds numbers.

Key Words :Elastic flow instabilities / Flow modes / Spherical Couette flow / Torque characteristics / Thrust characteristic
\end{abstract}

\section{粘弾性流体の同心同軸半球間陌流れ}

\author{
山口 博司 ${ }^{*}$ ，森下 昌俊
}

(原稿受理 : 2000年3月 15 日)

1. 緒言

ニュートン流体の球クエット流れでは, 内球回転一外球殼 静止の場合, 遠心力不安定性が生じ, 赤道付近に Taylor-Görtler vortex（以下，T.G. 渦）と呼ばれる安定な渦列が発生する ${ }^{1)}$. このT.G. 渦は超臨界状態にあり, さらにレイノルズ数の増加 に伴い時間的・空間的な流れの構造を幾段階にも変化させる 2),3). すなわちこれらを流れの遷移モードとしてとらえること ができる. 一方, 非ニュートン流体である粘弾性流体の回転 間隙流れでは, 遠心力不安定性のみならず, 弾性による不安 定性が複雑な流れを導くことが報告4) 6) されている．また，

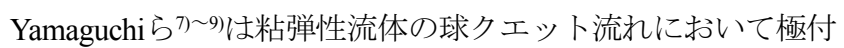
近よりリング状の境界が発生し, 遠心力が支配的な領域と弾 性が支配的な領域を形成することを実験的にも, また数值解 析的にも報告している.

通常, 粘弾性流体の球クエット流孔は低回転（低回転レイ ノルズ数) において, 内, 外球とも赤道対称であり, 上半球, 下半球の間隙流れは対称流れとなる.

一方, 内球を下半球のみにした場合, 流れの赤道対称性が 崩れ, 特に半球間隙では粘弾性流体が持つ法線応力効果によ り, 流線方向にせん断応力の他に張力が発生し, これと垂直 な方向に応力が生じる. 従って, 内および外球全表面には, 赤道非対称性によるスラスト力が生まれるものと考えられ

\footnotetext{
同志社大学工学部機械系学科

干 610-0321 京都府京田辺市多々羅都谷 1-3
}

る. このように半球クエット流れ（内球を半球にした外球款 との同心同軸間隙流れ）は，流体力学的基礎研究の見地から も, また各種攪拌機器, 化学・工業プラントにおける半球形状 非対称回転系流体機器, さらにレオロジー計測に用いられる 半球回転粘度計 ${ }^{16)}$ 等への工学的応用に関しても, 非常に自然 な流れの形態として取り上げられる。しかし，これらの基礎 流体的さらに工学的応用分野における重要性にも関わらず, 粘弾性流体の半球クエット流れに関しては，未だ十分に研究 がなされていないのが現状である.

そこで本研究では，粘弾性流体における外球殼静止時にお ける半球クエット流れに関して流れ場の挙動および特性に つき検討を行った．供試流体として希薄溶液でありながら比 較的粘弾性特性を良く示す PAA（Polyacrylamide）高分子の水 溶液を使用し，広範囲なレイノルズ数において内球表面トル ク，外球款表面に作用するスラスト力の計測を行うとともに 流れの可視化を行い，回転間隙のせん断場における粘弾性に より誘起される流れのモードの調査を行った.

\section{2. 実験}

\section{1 実験装置及び実験方法}

実験装置の概略を Fig.1 に示す. 内半球(1)は塩化ビニル製 で，外球殼(2)は可視化および写真撮影のためアクリル樹脂製 とした. 球クエット流れでは, 内球半径 $r_{1}$, また外球款内面 半径 $r_{2}$ とすると間隙比 $\beta=\left(r_{2}-r_{1}\right) / r_{1}$ が流れ場に対して非常に 

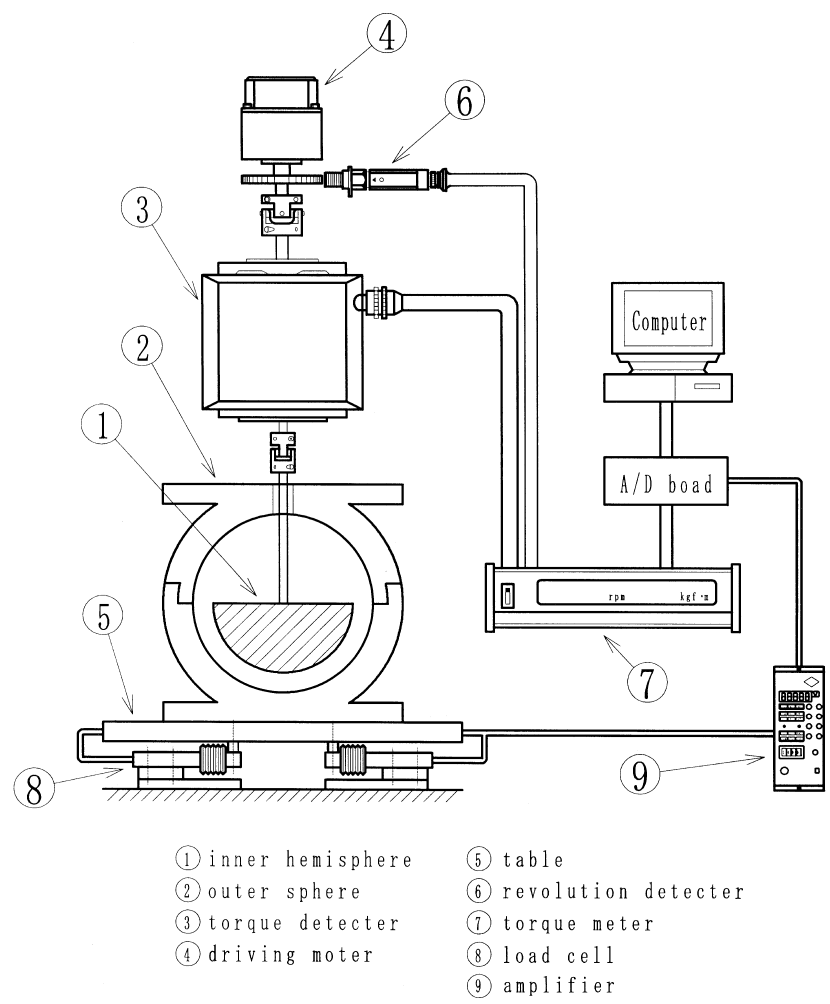

Fig.1 Schematic diagram of the apparatus.

Table I Variation of gap ratio.

\begin{tabular}{|c|c|c|}
\hline $\begin{array}{c}\text { radius of inner hemisphere } \\
r_{1}[\mathrm{~mm}]\end{array}$ & $\begin{array}{c}\text { radius of outer sphere } \\
r_{2}[\mathrm{~mm}]\end{array}$ & $\begin{array}{c}\text { gap ratio } \\
\beta=\left(r_{2}-r_{1}\right) / r_{1}\end{array}$ \\
\hline 65 & 70 & 0.0769 \\
65 & 75 & 0.1538 \\
65 & 78 & 0.2000 \\
\hline
\end{tabular}

Process accuracy of the radii is smaller than $| \pm 0.1| \%$.

大きな影響を及ぼすことが知られている3), 10). そこで, $r_{1}, r_{2}$ の選定に際し, 内球回転一外球殼静止時において遠心力不安 定性が発生し, T.G. 渦の存在が確認され, 間隙比が比較的狭 い場合とされる ${ }^{10)}$, (Table I に示すような $r_{1}, r_{2}$ の組み合わせ によって）3種類の間隙比 $\beta$ を用いることとした。ここで内 球および外球殼の表面は水力的平滑仕上げとした. 内半球回 転軸は直径 $8 \mathrm{~mm}$ のジュラルミン製である. Fig.1 に示すよう にこれらの球をカップリングを介し同心同軸に配置し，2球 間に供試流体を封入した。本研究では外球款を静止, 内半球 は，モータ(4)により回転させ回転数を回転検出器(6により， また内半球表面の摩擦トルクを内半球軸に直結されたトル ク検出器(3により測定した. 外球殼はテーブル(5)の上部に固 定し，テーブル(5)の下に設置されたロードセル (8)により外球 殼表面にかかるスラスト力を測定した. トルク検出器, ロー ドセルから出力された信号は, トルクメータ(7), アンプ(9に より, $\mathrm{A} / \mathrm{D}$ 変換を行ってコンピュータに入力し, 処理演算を 行った. なお, 本実験により求められるトルク, スラスト力 の計測值は，最大值において計測誤差はそれぞれ約 $\pm 0.1 \%$, 土1.0\%である.

実験に際しては, 流れのモードが回転加速度に影響される
ことを考慮し1)，内半球の回転数は準静的に変化させ，また 内半球の回転数を変える毎に充分な待ち時間（5分間）をお き, 流れのモードに変化がないことを確認した後に摩擦トル ク，スラスト力の測定を行った. 摩擦トルク，スラスト力計

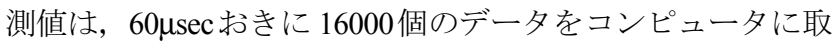
り込み，その平均值を代表データとした。，一方，流れの可視 化は供試流体の中にアルミニウム粉末を分散させることに より流れのモードを観測できるようにした．流れの可視化観 測は，外球殼表面を通して赤道面上より行い（Frontal view）, 赤道面をはさんでそれぞれ北半球, 南半球に現れる流れの様 相について目視観測を行なうとともに，写真撮影を行なっ た.ここで，供試流体に対するアルミニウム粉末の濃度は $0.02 \% w t$ 未満であり，供試流体の粘度および流れへの影響は 見られなかった。

なお，内半球回転の摩擦による流体の温度変化は全ての実 験条件下において約 $1^{\circ} \mathrm{C}$ 以下と非常に小さく，物性に対する 温度補正の必要性は認められなかった。また，実験環境温度 は実験装置全体を恒温室内に配置することで一定とし，この

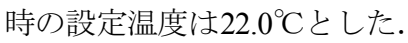

\section{2 供試流体}

本実験で用いた供試流体は，ニュートン流体としてグリセ リン水溶液，また，粘弾性流体（非ニュートン流体）として， 希薄溶液においても顕著な粘弾性のレオロジー特性を示し,

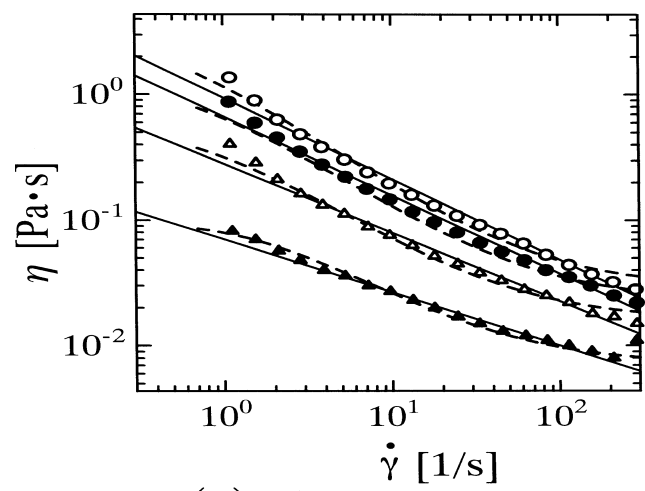

(1) Shear viscosity

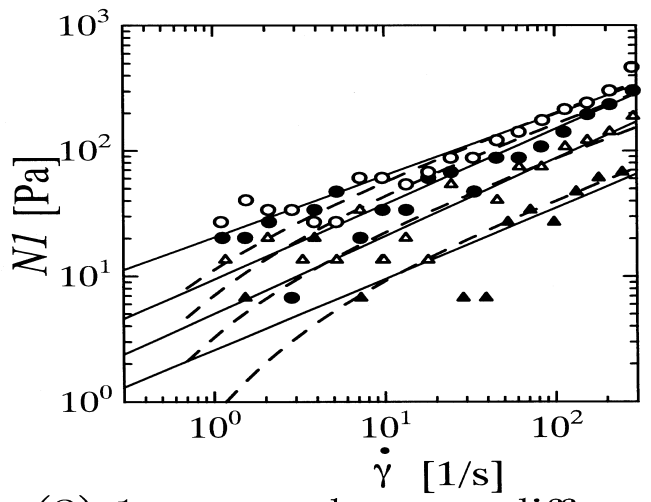

(2) 1 st normal stress difference

Fig.2 Rheological characteristics for PAA-water solutions.

A : PAA $500 ; \triangle$ : PAA 1000 ; : PAA $1500 ; \bigcirc$ : PAA2000 _ Power-law model ; - - - - Giesekus model 
物性も比較的制御しやすい Polyacrylamide（三洋化成製サンフ ロック $\mathrm{AH}-210 \mathrm{P}$, 分子量 $\left.\mathrm{M}_{\mathrm{n}} \approx 1.6 \times 10^{7}\right)$ 水溶液 $(500,1000,1500$, $2000 \mathrm{ppm}$ 溶液）を用いた ${ }^{11)}$. なお本実験では，これらの高分 子水溶液をPAA と称し, 溶液濃度別に区別した。

供試流体の作成にあたりPAAの溶解は擋拌器を用いて行 い, 擋拌速度, 擋拌時間, および溶解温度 $\left(22.0^{\circ} \mathrm{C}\right)$ に留意 し, 各々の溶液の物性を全ての実験において同一かつ均一と なるように配慮した。 これらの供試流体のレオロジ一特性の 計測結果をFig.2に示す.ここで Fig.2-(1)はせん断粘度 $\eta$ [Pas], (2)は第一法線応力差 $N_{1}[\mathrm{~Pa}]$ である. また, Fig.2-(1), (2)中に示 す実線, 破線はそれぞれ後に示す式(3)およびGiesekus モデ ル12)によるフィット曲線である.ささらに, Table IIに示すレオ ロジー物質定数 $m, n$ は, 式(3)のべき乗則流体における係数定 数である.これらの物質定数はコーンプレート型レオメータ で, せん断速度範囲（ $\dot{\gamma}=2 \sim 240[1 / \mathrm{s}])$ において測定した (Fig.2 に示す）粘度および第一法線応力差より算出した. ここで, 供試流体のレオロジー計測に使用したコーンプレート型レ オメータは，特に比較的低濃度の高分子水溶液のレオロジー 特性を計測するために制作したもので, せん断応力によるト ルクおよび法線応力によるスラスト力をひずみゲージ式変 位応力計測により最大約 $1.2 \%$ 計測誤差で測定できるもの である. また, 後述の弾性不安定性に起因する流れモード変 化の臨界問題を次元解析の視点より議論するため, 本研究で は供試流体のレオロジー特性の変化傾向を示す粘弾性モデ ルとしてGiesekusモデル12)を用い, それぞれ次元解析に必要 なパラメータの見積もりを行なった. Fig.2に示すように, べ き乗則流体モデルおよびGiesekus モデルによるデータフィッ トは, データの変化傾向を良く示す.

Table II Power-law model fitting parameters (range of shear rate : $2 \sim 240[1 / \mathrm{s}]$ ).

\begin{tabular}{|c|c|c|c|c|c|}
\hline & & $\begin{array}{c}m \\
{\left[\mathrm{mPa} \cdot \mathrm{s}^{n}\right]}\end{array}$ & $n$ & $\begin{array}{c}k \\
{\left[\mathrm{mPa} \cdot \mathrm{s}^{v}\right]}\end{array}$ & $v$ \\
\hline \hline \multirow{4}{*}{ PAA } & 500 & 70.497 & 0.5765 & 1.8879 & 0.5452 \\
\cline { 2 - 6 } & 1000 & 282.43 & 0.4518 & 5.0086 & 0.6193 \\
\cline { 2 - 6 } & 1500 & 668.52 & 0.3750 & 9.4023 & 0.6006 \\
\cline { 2 - 6 } & 2000 & 942.21 & 0.3562 & 20.306 & 0.4937 \\
\hline
\end{tabular}

(for the shear viscocity $\eta=m \dot{\gamma}^{n-1}$ and first normal stress difference $N_{1}=k \dot{\gamma}^{v}$ )

実験において, 供試流体の高せん断速度下における高分子 鎖状構造の破壊による物性の変化を避けるため実験 1 回のみ の使用とした. また, 経時変化による影響を避けるため PAA は溶解後24時間以内で使用した. さらに, 実験では計測前後 の供試流体の特性確認（レオロジー物性をレオメータで再度 計測）を行なった結果, 物性值にはレオロジー計測誤差範囲 においてほとんど変化がないことが示された.

\section{3. 結果および考察}

\section{1 理論的背景}

本研究で対象とする粘弾性流体は非圧縮性であり, 流れ場 は等温, また重力の影響は無視する. すなわち流れ場の支配 方程式は以下のように表される.

$$
\nabla \cdot v=0
$$

$$
\rho \frac{D v}{D t}=-\nabla p+\nabla \cdot \tau
$$

ここで, 式(1)は連続の式, 式(2)は Cauchy の運動方程式で

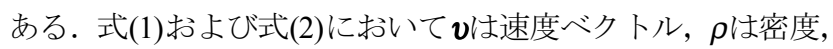
$t$ は時間, $p$ は圧力を示し, $\tau$ は応力テンソルを示す. 通常, 球 クエット流れでは, 内球あるいは外球の回転方法によらず遷 移領域に至るまでのレイノルズ数領域において流れの特性 は主に主流方向に対するせん断応力により支配される. そこ で本研究ではトルク測定実験のデータの整理に関し，せん断 場における供試流体の粘度の低下（Shear-thinning）を良く表 し,かつ簡素な構成方程式であるべき乗則流体モデル (Powerlaw モデル) を式(2)の応力テンソル 回転一外球殼静止時における内半球基準のトルク算出を行 うこととする.

$$
\tau_{12}=m \dot{\gamma}_{12}^{n}
$$

ここで， $\tau_{12}$ はせん断応力, $\dot{\gamma}_{12}$ はずり速度, $m, n$ は物質定数 である．ただし，べき乗則流体モデルは使用する物質定数が 2つと扱いやすい反面, 流体の粘度低下が見られるずり速度 領域のみにおいて有効な構成方程式であり，第一ニュートン 領域においては大きな誤差を生じるため適用範囲に制約が ある. しかし, 本研究の単純クエット流れ領域内における内 半球間隙流れの代表点（赤道面上の最大せん断速度を与える 点）のずり速度は, Table IIに示したべき乗則流体の有効ずり 速度の範囲内にあるため, べき乗則流体モデルの適用は充分 な精度を与えるものと考えられる.

次に, Fig.3 に示すような球座標系 $(r, \theta, \phi)$ を考え, 流 れは軸対称を仮定する. 内半球回転方向 $\omega$ に対する主流の流

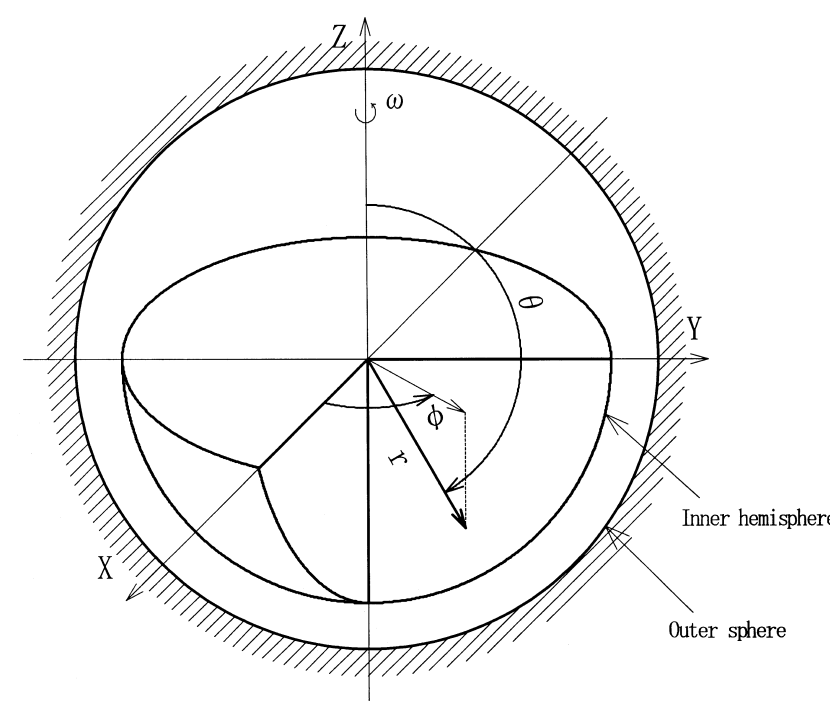

Fig.3 Spherical coordinate system.

れ方向を正とすると流体に働く内半球の $r$ 方向面におけるト ルク $T_{r}$ は, 


$$
T_{r}=2 \pi r_{1}^{3} \int_{\pi / 2}^{\pi} \tau_{r \phi} \sin ^{2} \theta d \theta
$$

と表せる. ここで， $\tau_{r \phi}$ は流体の微小要素 $(r$ 方向面）に働く $\phi$ 方向のせん断応力であり, べき乗則流体に対し以下の式で表 現できるものとする.

$$
\tau_{r \phi}=m\left\{r \frac{\partial}{\partial r}\left(\frac{v_{\phi}}{r}\right)\right\}^{n}
$$

単純クエット領域に相当する赤道面 $\left(\theta=90^{\circ}\right)$ において, 内 半球が回転角速度 $\omega$ で回転, 外球款静止の条件を考慮すると, 周方向速度 $v_{\phi}$ は式(2),(5)より，

$$
v_{\phi}=\left\{\frac{\omega r}{(1+\beta)^{3 / n}-1}\right\}\left\{\left(\frac{1+\beta}{\varepsilon}\right)^{3 / n}-1\right\}
$$

となる. ここで, 間隙比 $\beta$ を $\beta=\left(r_{2}-r_{1}\right) / r_{1}$, また無次元半径比 $\varepsilon$ を $\varepsilon=r / r_{1}$ とした. 次に, 流体密度 $\rho$ を用いてトルクの無次元 化を行い, 内半球の $r$ 方向面におけるトルク係数を以下のよう に定義する。

$$
C m_{r}=\frac{T_{r}}{\rho r_{1}^{5} \omega^{2}}
$$

従って, (4)(5)(6)(7)式より，

$$
C m_{r}=2 \pi \frac{1}{R e^{*}}(1+\beta)^{3}\left\{\frac{3 / n \cdot \beta}{(1+\beta)^{3 / n}-1}\right\}^{n} \int_{\pi / 2}^{\pi} \sin ^{2+n} \theta d \theta \text { (8) }
$$

となる. ここでRe*は一般化レイノルズ数であり， $\left(R e^{*}=\rho\left(r_{1} \omega\right)^{2-n}\right.$ $\left.\left(r_{2}-r_{1}\right)^{n} / m\right)$ で定義される.

同様に，流れは軸対称を仮定し内半球回転方向に対する主 流の流れ方向を正とすると, 流体に働く内半球の赤道上 $\theta$ 方 向面におけるトルク $T_{\theta}$ は,

$$
T_{\theta}=2 \pi \int_{0}^{r_{1}} \tau_{\theta \phi} r^{2} d r
$$

と表せる. ここで, $\tau_{\theta \phi}$ は流体の微小要素 $(\theta$ 方向面）に働く $\phi$ 方向のせん断応力であり, 内半球が角速度 $\omega$ で回転, 外球款 静止の条件で赤道面 $\left(\theta=90^{\circ}\right)$ においてせん断速度 $\gamma_{\theta \phi}$ の $\phi$ 方向 分布を線形近似する場合, べき乗則流体に対し以下の式で表 現できるものとする.

$$
\tau_{\theta \phi}=m\left\{\frac{\omega r}{\sqrt{r_{2}^{2}-r^{2}}}\right\}^{n}
$$

次に, 流体密度 $\rho$ を用いてトルクの無次元化を行い, 内半 球の赤道上 $\theta$ 方向面におけるトルク係数を以下のように定義 する.

$$
C m_{\theta}=\frac{T_{\theta}}{\rho r_{1}^{5} \omega^{2}}
$$

従って，(9)(10)(11)式より，

$$
C m_{\theta}=2 \pi \frac{1}{R e^{*}} \frac{\left(r_{2}-r_{1}\right)^{n}}{r_{1}^{3+n}} \int_{0}^{\eta} r^{2+n}\left(\frac{1}{\sqrt{r_{2}^{2}-r^{2}}}\right)^{n} d r
$$

以上より，内半球全表面にかかるトルクは，

$$
\begin{aligned}
& C m=C m_{r}+C m_{\theta} \\
& =\frac{2 \pi}{R e^{*}}\left[\left(\frac{3 / n \cdot \beta}{(1+\beta)^{3 / n}-1}\right)^{n}(1+\beta)^{3} \int_{\pi / 2}^{\pi} \sin ^{2+n} \theta d \theta\right. \\
& \left.\quad+\frac{\left(r_{2}-r_{1}\right)^{n}}{r_{1}^{3+n}} \int_{0}^{r_{1}} r^{2+n}\left(\frac{1}{\sqrt{r_{2}^{2}-r^{2}}}\right)^{n} d r\right]
\end{aligned}
$$

となる. 一方, 鉛直下向きを正とすると外球款の $r$ 方向面にお けるスラスト力 $F_{t}$ は,

$$
F_{t}=2 \pi \int_{0}^{\pi}\left(\tau_{r \theta} \sin \theta-\tau_{r r} \cos \theta\right) r_{2}^{2} \sin \theta d \theta
$$

と表せる. 同様にして流体密度 $\rho$ を用いてスラスト力の無次 元化を行い, 内半球が角速度 $\omega$ で回転，外球壳静止の条件で 外球殼の $r$ 方向面におけるスラスト係数を以下のように定義 する.

$$
\operatorname{Tm}=\frac{F_{t}}{\rho r_{1}^{4} \omega^{2}}
$$

さらに粘弾性流体の単純せん断流れにおいては，弾性によ る法線応力が流線に張力を及ぼし，その結果，流線と弾性に よる法線応力の相互作用から弾性不安定性が発生すること が実験的・解析的に広く報告されている ${ }^{4}$. そこで，実験よ り得られた弾性不安定性に起因する流れのモード変化と間 隙比に対する臨界值を統一的に整理する上で，弾性不安定性 の発生するパラメータとして, Giesekus モデルを考慮した マッキンリー数 ${ }^{13)} M\left(M_{\text {crit }}\right.$ は臨界マッキンリー数を示す) を 導入する.

$$
\left\{\frac{\lambda_{1} \widetilde{J}}{\Re}\left(\lambda_{1} \dot{\gamma}\right)\left[\frac{\Psi_{1}(\dot{\gamma})}{2 \chi_{p} \lambda_{1}}\right]\left[\frac{\lambda(\dot{\gamma})}{\lambda_{1}}\right]\right\}^{1 / 2} \geq \frac{M_{\text {crit }}}{\sqrt{2(1-\Lambda)}}
$$

ここで式(16)において， $\Psi_{1}(\dot{\gamma}) お よ ひ ゙ \lambda(\dot{\gamma})$ はそれぞれ第一法 線応力係数および緩和時間を示寸物性関数 ${ }^{14)}$ で, $\lambda_{1}, \chi_{0}, \chi_{p}$ お よび $\chi_{s}$ はそれぞれ代表緩和時間，ゼロせん断粘度，高分子に よるせん断粘度への寄与また溶媒によるせん断粘度への寄 与 ${ }^{14)}$ を示吉物質定数で， $\Lambda$ は $\chi_{s} / \chi_{0}$ を示す. これらのパラメー 夕はFig.2に示されるように, Giesekus モデルにより供試流体 のレオロジー特性の変化傾向を示すモデルパラメータとし

Table III Giesekuse model fitting parameters (range of shear rate : $2 \sim 240[1 / \mathrm{s}]$ )

\begin{tabular}{|c|c|c|c|c|c|}
\hline & & $\begin{array}{c}\chi_{p} \\
{[P a \cdot s]}\end{array}$ & $\begin{array}{c}\chi_{s} \\
{[\mathrm{mPa} \cdot s]}\end{array}$ & $\begin{array}{c}\chi_{0} \\
{[P a \cdot s]}\end{array}$ & $\begin{array}{c}\lambda_{1} \\
{[s]}\end{array}$ \\
\hline \hline \multirow{4}{*}{ PAA } & 500 & 0.0881 & 7.225 & 0.0953 & 6.25 \\
\cline { 2 - 6 } & 1000 & 0.5145 & 16.15 & 0.5307 & 7.55 \\
\cline { 2 - 6 } & 1500 & 1.201 & 23.04 & 1.224 & 8.53 \\
\cline { 2 - 6 } & 2000 & 3.196 & 29.20 & 3.225 & 9.55 \\
\hline
\end{tabular}


て求められる.ここで, これら供試流体のGiesekus モデルに よるモデルパラメータをTable III に示す.さらに，式(16)にお いてひおよびィはそれぞれ球クエット流れにおいては代表 速度および代表曲率で, 本研究では次式の関係式で定義し た.

$$
\widetilde{\mho}=v_{\phi}=r_{1} \omega \sin \theta, \quad \Re=r_{1} \sin \theta
$$

\section{2 結果及び考察}

Fig.4にグリセリン水溶液, 各PAA水溶液に対する $\mathrm{Cm}$ と $R e^{*}$ の関係を示す. 式(13)はShear-thinningを考慮した理論式であ り，図からわかるように二次流れの影響が無視される単純ク エット領域においては, 式(13)とCmはすべての実験データに

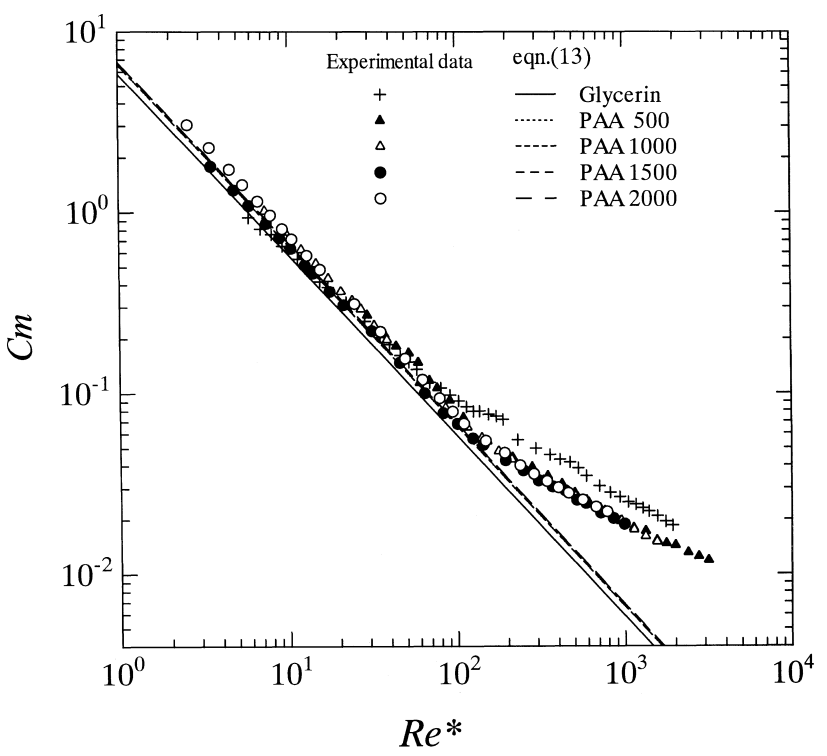

Fig.4 Generalized Reynolds number versus torque coefficient for glycerine and PAA-water solutions $(\beta=0.1538)$.

対して良い一致を示すことがわかる. PAA水溶液の $C m$ とグリ セリン水溶液のものと同レイノルズ数にて比較した場合，前 者のほうが相対的に大きくなる。これはshear-thinningにより 壁近傍でのせん断速度の非線形性が強くなるためであり，こ の傾向は濃度が高いほど強くなることが確められた．このこ とはポアズイユ流れにも見られる現象である ${ }^{13)}$. 同様にして, Fig. 5 にグリセリン水溶液, 各PAA水溶液に対する $T m$ と $R^{*}$ の 関係を示す.ここで, PAA水溶液固有のスラスト特性として, 正值の $T m$ をとるレイノルズ数の領域が存在することである. 即ち, グリセリン水溶液では, すべてのレイノルズ数でTmは 負の值 $(-0.0924 〜-0.0312)$ となるのに対し, PAA水溶液で は低レイノルズ数領域において, (例えば, Fig. 5 より PAA2000 ではほぼ $R e^{*}=230$ までにおいて）正值である。これは, 粘弾性 流体がもつ法線応力効果によるものと考えられる. 特に, 南 半球の間隙流れでは流線方向にせん断応力の他に張力が発 生し, それと垂直な方向に圧力が生じるため, 外球殼の南半 球部分を鉛直下向きに押し下げるものと考えられる.また, 同じレイノルズ数において, PAA水溶液のTmは, 弾性の影響

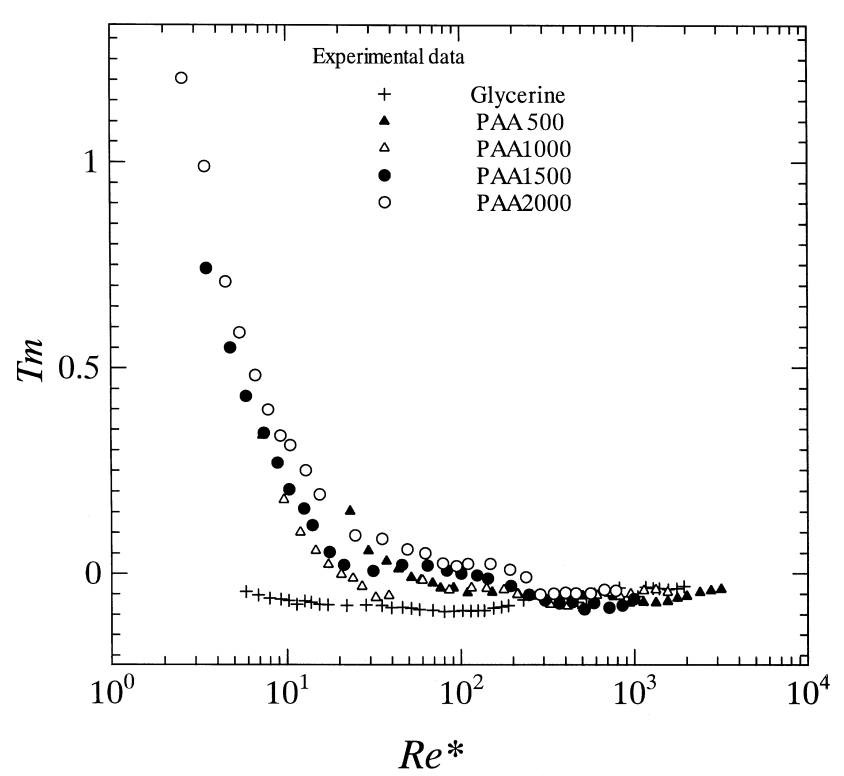

Fig.5 Generalized Reynolds number versus thrust coefficient for glycerine and PAA-water solutions $(\beta=0.1538)$.

が強いPAA2000のTmが最大を示し，PAA500のTmが最小とな り，TmはPAAの濃度に強く依存することが明らかとなった。 ここで, 本研究ではTmに対しては, 式(13)に示すような実験 式を与えることができなかった. 即ち，式(14)に現れる $\tau_{r \theta}$ お よび $\tau_{r r}$ に対応する速度場の見積もりが非常に困難なためであ る(最も単純なPower-lawモデルにおいても速度場の近似が困 難となる）。従って，本報告では粘弾性効果によるスラスト 力の存在を確認するにとどめ, $T m$ の予測に関しては数值解析 的手法による研究に期し, 将来的な研究としたい.

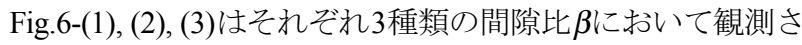
れた超臨界領域における PAA 水溶液の流れのモード図であ り，可視化実験より得られた結果を Table IVに示す6種類の流 れモードに分類し, 弾性不安定性の発生パラメータである臨 界マッキンリー数（式(16)）参照）をレイノルズ数に対して 表したものである.

なお，本研究で使用するマッキンリー数の定義式(16)中の せん断速度は, 赤道上の内半球壁を代表点として以下の式,

$$
\dot{\gamma}=\frac{3 \omega}{1-(1+\beta)^{-3}}
$$

で定義した ${ }^{14)}$.ここで, Table IVにおける基本的な 6 種類の流 れは，表中に示されるように，外球殼表面を通しての観測お よび南半球の間隙における観測結果より総合的に判断した ものである．以下に流れの様相について述べる．まず，本研 究で観測された最も基本的な流れの形態である $\mathrm{Ll}$ は，北半球 においては“upper vortex”（後述）をともなう二次流れを，ま た南半球の間隙では非常に弱い二次元流れをもつクエット 流となる流れのモードを示す，次に，Ltは北半球ではLl と同 じ流れの様相を示すものの, 南半球の間隙にT.G. 渦 ${ }^{1)}$ が発生す る流れのモードを示す.さらに, Ltsでは南半球の間隙に生じ たT.G. 渦がスパイラル構造2),3)を持つものである. LStでは逆 に北半球においてスパイラル構造をもつT.G. 渦が発生するも 


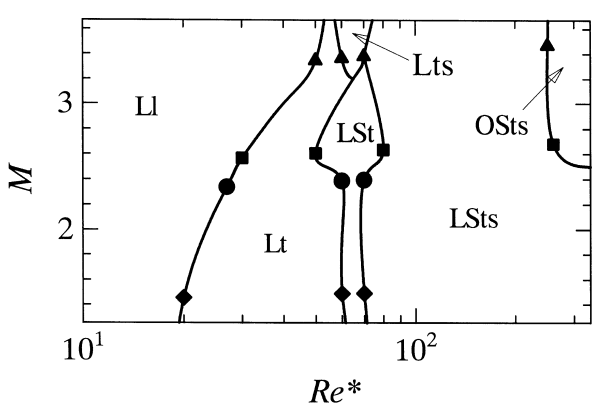

(1) $\beta=0.0769$

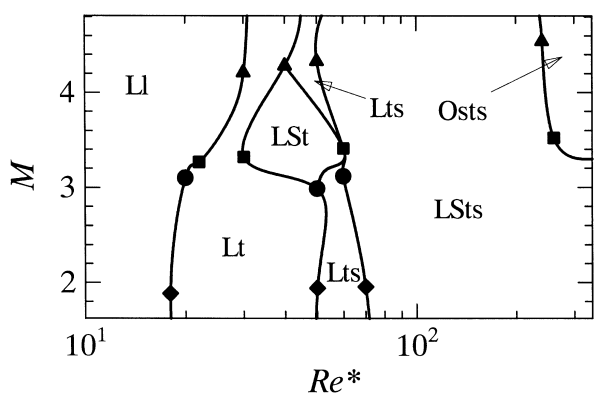

(2) $\beta=0.1538$

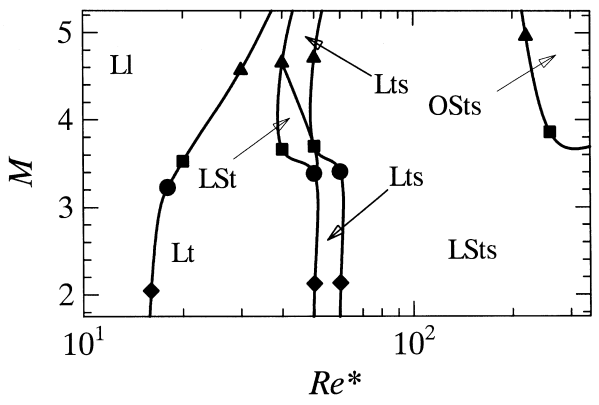

(3) $\beta=0.2000$

Fig.6 Dependence of flow modes on the Reynolds number and Mckinley number.

$\Delta$ : PAA500

: PAA 1000

: PAA 1500

: PAA2000

Table IV Flow mode classification of PAA-water solutions.

\begin{tabular}{|c|c|c|}
\hline \multirow{2}{*}{ Mode } & \multicolumn{2}{|c|}{ Characteristics } \\
\cline { 2 - 3 } Ll & $\begin{array}{c}\text { Upper hemisphere } \\
\text { or } \begin{array}{c}\text { Laminar+secondary flow } \\
+ \text { upper vortex }\end{array}\end{array}$ & Hemisphere gap \\
\hline Lt & $\begin{array}{c}\text { Laminar } \\
\text { or } \quad \begin{array}{c}\text { Laminar+secondary flow } \\
+ \text { upper vortex }\end{array}\end{array}$ & TG vortex \\
\hline Lts & $\begin{array}{c}\text { Laminar } \\
\text { Laminar+secondary flow } \\
+ \text { upper vortex }\end{array}$ & $\begin{array}{c}\text { TG vortex } \\
\text { +spiral TG vortex }\end{array}$ \\
\hline LSt & $\begin{array}{c}\text { Laminar+secondary flow } \\
+ \text { upper vortex } \\
+ \text { spiral TG vortex }\end{array}$ \\
\hline LSts & $\begin{array}{c}\text { Laminar+secondary flow } \\
+ \text { upper vortex } \\
+ \text { spiral TG vortex }\end{array}$ & $\begin{array}{c}\text { TG vortex } \\
\text { +spiral TG vortex }\end{array}$ \\
\hline OSts & Oscillating+spiral TG vortex & $\begin{array}{c}\text { TG vortex } \\
+ \text { spiral TG vortex }\end{array}$ \\
\hline
\end{tabular}

のの, 南半球の間隙では通常のT.G. 渦のみが存在する流れの モードを示す. 一方LStsでは, 北半球及び南半球の間隙に生 じたT.G. 渦がともにスパイラル構造をもつ流れのモードを示 す. 最後に, OStsではLStsにおいて存在した, 最も基本的な 流れの形態すなわち, “upper vortex”をともなう二次流れが,
振動を開始し北半球全体がスパイラルT.G. 渦をともなう複雑 な流れとなるモードを示す. 次に, Fig.6-(1), (2), (3)を比較し た場合，それぞれ流れのモードは類似した傾向を示すもの の, 間隙比が小さくなるにつれて LStの領域が低いマッキン リー数において発生する特徴が分かる.さらに，これに伴い Ltsの領域が大きく変化する影響を受けることが示された。こ のように, 本実験で確認された PAA 水溶液特有の流れのモー ドは Fig.6に示すように，マッキンリー数を考慮することに よって非常に良く整理できることが分かった，以下，（Table IVによるモード分類に従った）モード図で，代表例として， $\beta=0.1538$, PAA2000の場合（Fig.6-(2)参照）について説明する. 始めに, マッキンリー数が $M=1.89\left(R e^{*}=6.524\right)$ までは北，南 半球とも単純二次流れであるモードL1を維持する。 ここで特 に，北半球の $\theta$ 面上には，本研究により存在が示された非常 に微弱な輪状の循環渦の発生が認められる。本研究では以 下，この輪状構造を持つ渦を“upper vortex”と呼称する. Fig.7 に“upper vortex”の可視化例及びスケッチを示す．図に示され るように, upper vortex は, 子午面上における北半球 $\theta$ 面上の 外球款よりに位置し, 北半球 $\theta$ 面上における二次流れの $r$ 方向 成分が逆流することにより形成される.この渦は, 北半球 $\theta$

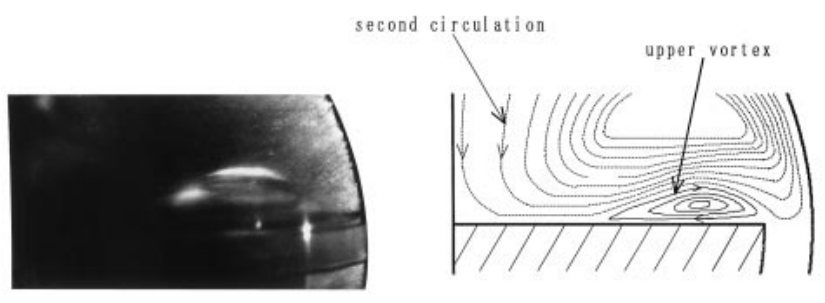

upper vort ex

Fig.7 The existence of "upper vortex"(flow visualization and schematic drawing of the flow field strucure for the cross section (PAA2000)).

面上における半径方向流れ（二次流れ）の剥離が原因と考え られる．また，この渦領域はグリセリン，PAA水溶液共に見 受けられるものの非常に微弱であるため可視化実験におい ても肉眼での観察は困難を極めた（ただし，高濃度PAA水溶 液では比較的その存在が明らかとなる). $M=1.89\left(R e^{*}=6.524\right)$ か らは，南半球の赤道付近より Fig. 8-(1)に示すような輪状構造 をもつ渦が発生する (Lt). 渦の発生は, 遠心力不安定性によ る影響が大きく，さらに弾性の影響も加わり幾度とその形を 変化させるPAA 水溶液特有のT.G. 渦と推察される. また, Fig.8-(2) に示すように, 半球回転速度の増加により $M$ $=1.94\left(R e^{*}=34.984\right)$ では南半球の赤道付近に発生したT.G. 渦は, 南極方向に進行しスパイラルT.G. 渦となる (Lts) . さらに, Fig.8-(3)に示すように高い半球回転速度に対して $M=1.96\left(R e^{*}\right.$ =60.823)では, 南半球だけでなく北半球にもスパイラルT.G. 渦が発生した (LSts).このスパイラルT.G.渦は，北半球の赤 道付近から北極方向に進行するものの, 南半球のスパイラル T.G. 渦と比べて，発生の時間間隔や渦列の空間的間隔も全く 異なり赤道面に非対称な流れのモードである，以上，粘弾性 流体の半球間隙流れに対する (Fig. 6に示されるようなPAA水 


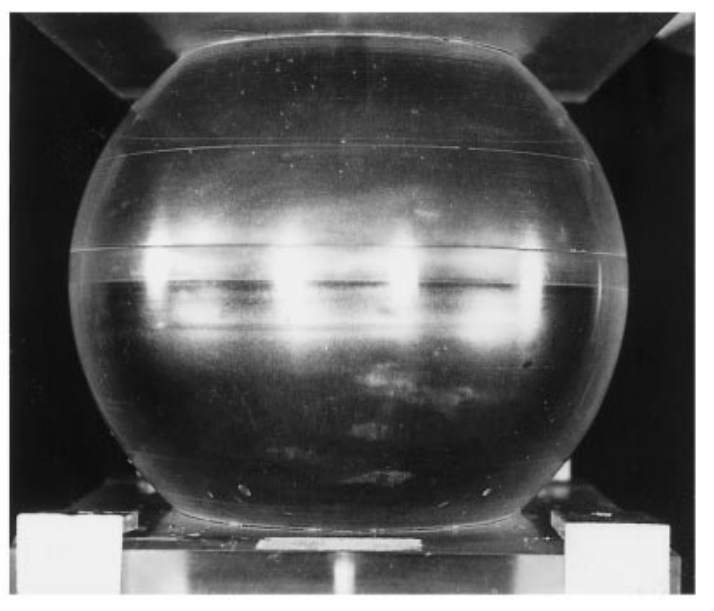

(1) mode Lt $\left(\mathrm{Re}^{*}=6\right)$.

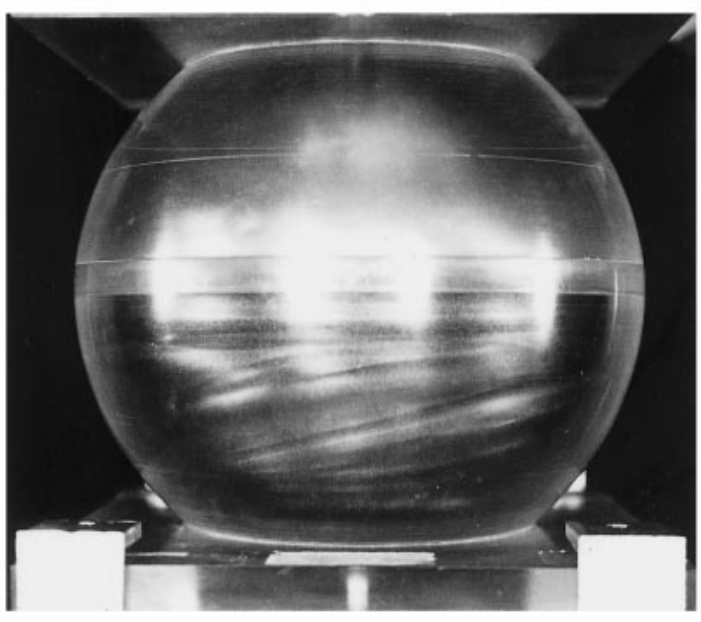

(2) mode Lts $\left(\operatorname{Re}^{*}=35\right)$.

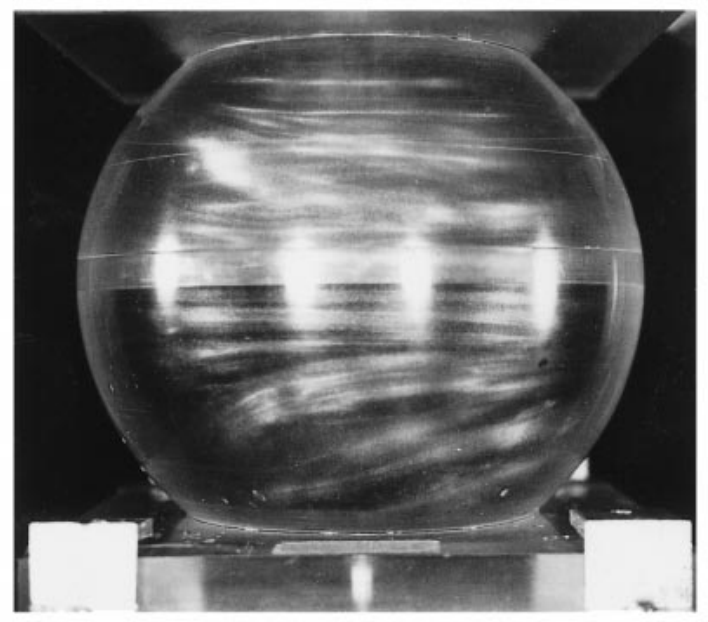

(3) mode LSts $\left(\operatorname{Re}^{*}=61\right)$.

Fig.8 Typical flow modes for the PAA-water solution (PAA2000, $\beta=0.1538)$.
溶液特有の）流れのモードの発生原因として，赤道付近の遠 心力不安定性と粘弾性流体の持つ弾性不安定性の影響が考 えられる. 一方, 内半球回転一外球款静止時の球クエット流 れでは極付近より帯状構造を示す渦が発生することが, Yamaguchi (7)よって報告されているものの, 本研究の実験 範囲では，それらのような弾性不安定性のみに起因するよう な流れのモードは認知されなかった. 以上の可視化実験の結 果より, 粘弾性流体特有のスパイラルT.G. 渦は弾性の効果が 強ければ低レイノルズ数領域においても発生する傾向がみ られ，溶液の濃度が高くなるほど不安定性現象が生じやすい 傾向を示すことが確認された.

\section{4. 結言}

本研究の内半球回転一外球殼静止時における粘弾性流体 の同心同軸半球閒隙流れに関して次のような結論を得た.

1. 流体力学的安定な低レイノルズ数において, 理論式 (13) でトルク係数 $C m$ を良く表現できることがわかった.

2. 粘弾性流体の外球表面に作用するスラストの測定結果 から，同レイノルズ数の場合，Tmは溶液濃度が高いほど大 きくなり, 内球を半球にすることにより，粘弾性流体の法 線応力効果が確かめられた.

3. マッキンリー数を用いることによって弾性不安定性に 起因する流れのモードは良くまとめられる. 特に, 北半球 の $\theta$ 面上には, 非常に微弱な循環渦の存在が確認され, 高 濃度PAA水溶液においてその存在はより顕著になることが 示された.

謝 辞

本研究の一部は, 文部省の補助による同志社大学大学院 RCAST の支援を受けた，記して謝意を表す。また，本研究の 遂行にあたり, 多大な御助言, 御助力を賜った同志社大学工 学部押目教授に感謝の意を表す。

\section{参考文献}

1) Wimmer M, J Fluid Mech, 78, 317 (1976).

2) Nakabayashi K, J Fluids Eng, 100, 97 (1978).

3) 中村功一, 機論, 63, 3499 (1997).

4) Larson R G, Rheolo Acta, 31, 213 (1992).

5) McKinley G H, Byars J A, Brown R A, Armstorong R C, $J$ Non-Newtonian Fluid Mech, 40, 201 (1991).

6) Shaqfeh E S G, Muller S J, Larson R G, J Fluid Mech, 235, 285 (1992).

7) Yamaguchi H, Fujiyoshi J, Matsui H, J Non-Newtonian Fluid Mech, 69, 29 (1997).

8) 山口博司，西口文吾，日本レオロジー学会誌 , 26, 169 (1998).

9) Yamaguchi H, Fujiyoshi J, Matsui H, J Non-Newtonian Fluid Mech, 69, 47 (1997). 
10) Egbers C, Rath H J, Acta Mechanica, 111, 125 (1995).

11) Rofe C J, Lambert R K, Callanghan P T, $J$ Rheol, 38, 875 (1994).

12) Giesekus H, J Non-Newtonian Fluid Mech, 11, 69 (1982).

13) McKinley G H, Pakdel P, Ozetekin A, J Non-Newtonian Fluid Mech, 11, 69, (1982)
14) 中村喜代次, “非ニュートン流体力学”, (1997), コロナ 社 東京。

15) Joo Y J, Shaqfeh E S, J Fluid Mech, 262, 27 (1994).

16) 小川 明, “レオロジー概論”, (1991), 山海堂 東京. 